\title{
Propranolol in hypertension: a dose-response study
}

\author{
D B GALLOWAY, S C GLOVER, W G HENDRY, A W LOGIE, J C PETRIE, M C SMITH, \\ J A LEWIS, W T SIMPSON
}

British Medical fournal, 1976, 2, 140-142

\begin{abstract}
Summary
The effect of propranolol was studied in a double-blind crossover trial in 24 carefully selected hypertensive outpatients. Each patient received propranolol $60 \mathrm{mg} / \mathrm{day}$, $120 \mathrm{mg} / \mathrm{day}, 240 \mathrm{mg} / \mathrm{day}$, and placebo for four weeks each according to a randomised sequence. Propranolol 60 $\mathrm{mg} /$ day was no better than placebo in reducing blood pressure. The effects of propranolol $120 \mathrm{mg} /$ day and $240 \mathrm{mg} /$ day were not significantly different. Both doses reduced lying blood pressure by about $20 / 10 \mathrm{~mm} \mathrm{Hg}$ from an initial level of $173 / 104 \mathrm{~mm} \mathrm{Hg}$. No difference was detected between the effects of the different doses of propranolol and placebo on weight or on the occurrence of adverse reactions.
\end{abstract}

\section{Introduction}

Propranolol is the most widely used beta-adrenoceptor antagonist in the treatment of hypertension and has been available for 11 years. Nevertheless, the optimum dosage regimen has not been established, and although incremental dosage studies have been carried out we have been unable to trace a within-patient crossover study that compares the effects of different doses in hypertensive patients. We report a controlled assessment of oral propranolol at three doses $(60,120,240 \mathrm{mg} /$ day) in outpatients with mild hypertension. Because the time of onset of the

Department of Therapeutics and Clinical Pharmacology, University of Aberdeen, Aberdeen AB9 2ZD

D B GALLOWAY, MRCP, lecturer

S C GLOVER, MRCP, resident medical officer

W G HENDRY, MRCP, resident medical officer

A W LOGIE, MRCP, lecturer

J C PETRIE, MRCP, senior lecturer

M C SMITH, co-ordinator

Imperial Chemical Industries Limited, Macclesfield, Cheshire

J A LEWIS, MA, statistician

W T SIMPSON, MB, member of clinical research department antihypertensive effect is not established we also observed the effect of two separate single oral doses $(20,80 \mathrm{mg})$ on hypertensive inpatients.

\section{Patients and methods}

Selection of patients-The procedure that was followed is described in $\overrightarrow{\vec{\omega}}$ the accompanying paper ( $p$ 137). Patients were invited to participate $O$ in the outpatient trial if their morning diastolic pressures were over $90 \frac{5}{3}$ $\mathrm{mm} \mathrm{Hg}$ and under $105 \mathrm{~mm} \mathrm{Hg}$ and all other outpatient and ward blood pressures confirmed persistent readings above $90 \mathrm{~mm} \mathrm{Hg}$.

Conduct of outpatient trial-After discharge from hospital the patients were seen at the hypertension clinic within two weeks. The $\infty$ design used was identical to that used in a previous study to assess the $\vec{A}$ efficacy of practolol. ${ }^{1}$ A double-blind crossover method was used to $\overrightarrow{0}$ assess the effects on lying, standing, and postexercise blood pressure $ᄋ$ of the following four treatments, each provided by two identical-looking tablets and given thrice daily: (a) propranolol $20 \mathrm{mg}$; $(b)$ propranolol $40 \mathrm{mg}$; (c) propranolol $80 \mathrm{mg}$; $(d)$ placebo. Each treatment was given $\subseteq$ for four weeks and each patient received the four treatments. The order of administration was determined by a random code that ensured $\overrightarrow{0}$ that each of the 24 possible permutations of four treatments was given to one of the 24 patients. Thus each treatment period followed or preceded any other treatment period on six occasions. Four-week supplies of drugs were given to each patient in prepacked and paired containers. The conduct of the trial and the statistical techniques used $\bar{\partial}$ were identical to those described in the accompanying paper.

Single-dose inpatient open study-Before discharge from hospital $13 \stackrel{\square}{\mathbb{D}}$ patients shown to be suitable for inclusion in this or other trials were given single test doses of oral propranolol, $20 \mathrm{mg}$ and $80 \mathrm{mg}$, at the 0 same time of day with at least 24 hours between the doses. The 3 observer of lying and standing blood pressures was the same for each patient (SCG or WGH). Duplicate measurements were made of lying and standing blood pressures at $0,30,60,90,120$, and 240 minutes with Hawksley random-zero machines.

\section{Results}

OUTPATIENT STUDY

Twenty-four patients (six men) aged 19-65 years (mean 46 years) ${ }_{N}$ with a mean initial weight of $62.6 \mathrm{~kg}(49.5-84.9 \mathrm{~kg})$ completed the trial. There were no defaulters and a complete set of observations was $\frac{7}{0}$ available for each patient. Tablet counts were satisfactory throughout $(>90 \%)$.

Mean values $( \pm \mathrm{SE}$ ) for blood pressure, pulse, and weight during $N$ the different treatment periods are shown in table I. The results are

TABLE I-Mean blood pressure, pulse, and weight $( \pm S E)$ in 24 patients

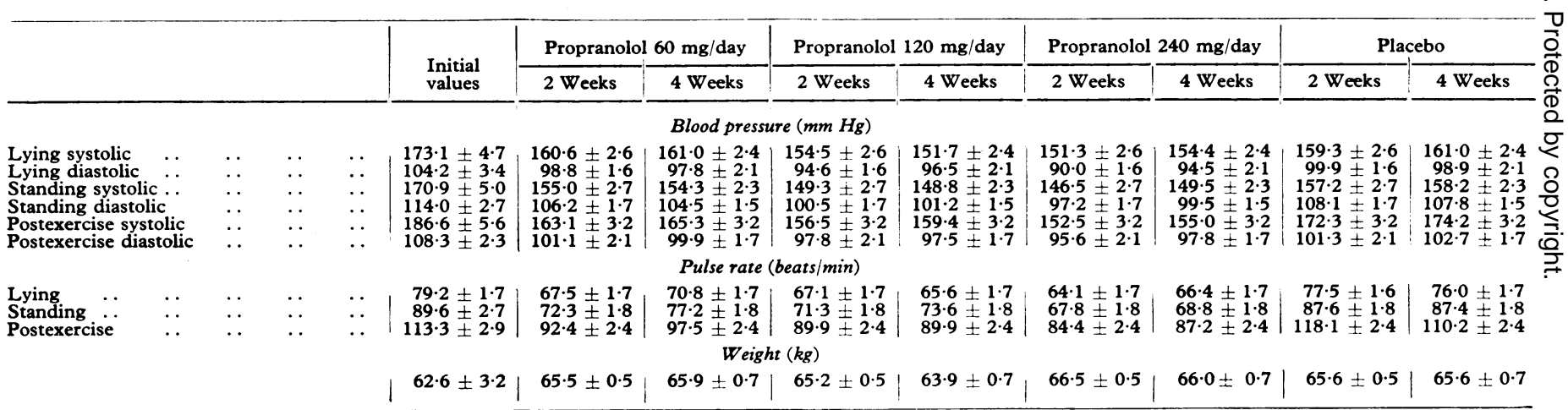


TABLE II-Comparison of treatments ( $P$ values) after two and four weeks of treatment in 24 patients

\begin{tabular}{|c|c|c|c|c|c|c|c|c|c|c|}
\hline & \multirow[b]{2}{*}{ Weeks } & \multicolumn{3}{|c|}{ Lying } & \multicolumn{3}{|c|}{ Standing } & \multicolumn{3}{|c|}{ Postexercise } \\
\hline & & $\begin{array}{c}\text { Systolic } \\
\text { BP }\end{array}$ & $\begin{array}{c}\text { Diastolic } \\
\text { BP }\end{array}$ & Pulse & $\begin{array}{c}\text { Systolic } \\
\text { BP }\end{array}$ & $\begin{array}{c}\text { Diastolic } \\
\text { BP }\end{array}$ & Pulse & $\begin{array}{c}\text { Systolic } \\
\text { BP }\end{array}$ & $\begin{array}{c}\text { Diastolic } \\
\text { BP }\end{array}$ & Pulse \\
\hline $\begin{array}{l}\text { Propranolol } 60 \mathrm{mg} \text { day } v 120 \mathrm{mg} \text { day } \\
\text { Propranolol } 60 \mathrm{mg} / \text { day } v 240 \mathrm{mg} / \text { day } \\
\text { Propranolol } 60 \mathrm{mg} / \text { day } v \text { placebo } \\
\text { Propranolol } 120 \mathrm{mg} / \text { day } v 24 \mathrm{mg} / \text { day } \\
\text { Propranolol } 120 \mathrm{mg} / \text { day } v \text { placebo } \\
\text { Propranolol } 240 \mathrm{mg} \text { /day } v \text { placebo }\end{array}$ & $\begin{array}{l}2 \\
4 \\
2 \\
4 \\
2 \\
4 \\
2 \\
4 \\
2 \\
4 \\
2 \\
4\end{array}$ & $\begin{array}{l}\text { NS } \\
<0 \cdot 01 \\
<0.02 \\
\text { NS } \\
\text { NS } \\
\text { NS } \\
\text { NS } \\
\text { NS } \\
\text { NS } \\
<0 \cdot 01 \\
<0.05 \\
\text { NS }\end{array}$ & $\begin{array}{l}\text { NS } \\
\text { NS } \\
<0.001 \\
\text { NS } \\
\text { NS } \\
\text { NS } \\
<0.05 \\
\text { NS } \\
<0.05 \\
\text { NS } \\
<0.001 \\
\text { NS }\end{array}$ & $\begin{array}{l}\text { NS } \\
<0.05 \\
\text { NS } \\
\text { NS } \\
<0.001 \\
<0.05 \\
\text { NS } \\
\text { NS } \\
<0.001 \\
<0.001 \\
<0.001 \\
<0.001\end{array}$ & $\begin{array}{l}\text { NS } \\
\text { NS } \\
<0.05 \\
\text { NS } \\
\text { NS } \\
\text { NS } \\
\text { NS } \\
\text { NS } \\
<0.05 \\
<0.01 \\
<0.01 \\
<0.02\end{array}$ & $\begin{array}{l}<0.05 \\
\text { NS } \\
<0.001 \\
<0.02 \\
\text { NS } \\
\text { NS } \\
\text { NS } \\
\text { NS } \\
<0.01 \\
<0.01 \\
<0.001 \\
<0.001\end{array}$ & $\begin{array}{l}\text { NS } \\
\text { NS } \\
\text { NS } \\
<0.01 \\
<0.001 \\
<0.001 \\
\text { NS } \\
\text { NS } \\
<0.001 \\
<0.001 \\
<0.001 \\
<0.001\end{array}$ & $\begin{array}{l}\text { NS } \\
\text { NS } \\
<0.05 \\
<0.05 \\
<0.05 \\
\text { NS } \\
\text { NS } \\
\text { NS } \\
<0.01 \\
<0.01 \\
<0.001 \\
<0.001\end{array}$ & $\begin{array}{c}\text { NS } \\
\text { NS } \\
\text { NS } \\
\text { NS } \\
\text { NS } \\
\text { NS } \\
\text { NS } \\
\text { NS } \\
\text { NS } \\
<0.05 \\
\text { NS } \\
0.05\end{array}$ & $\begin{array}{c}\mathrm{NS} \\
<0.05 \\
<0.01 \\
<0.01 \\
<0.001 \\
<0.001 \\
\mathrm{NS} \\
\mathrm{NS} \\
<0.001 \\
<0.001 \\
<0.001 \\
<0.001\end{array}$ \\
\hline
\end{tabular}

BP $=$ Blood pressure. $\quad$ NS $=$ Not significant.

also shown in figs 1 and 2 . The mean initial lying blood pressure was $173 / 104 \mathrm{~mm} \mathrm{Hg}$, and the mean reduction of lying blood pressure was about $20 / 10 \mathrm{~mm} \mathrm{Hg}$, achieved with daily doses of both $120 \mathrm{mg}$ and $240 \mathrm{mg}$; eight and nine patients respectively achieved a lying diastolic blood pressure of under $90 \mathrm{~mm} \mathrm{Hg}$ on these doses. There was no evidence that the effect of a given dose was greater after four weeks than after two.

The comparison of treatments is summarised in table II. The overall tests of significance showed that, in general, significant differences $(\mathbf{P}<0.05$ at least) existed between treatments in terms of their effect on blood pressure and pulse. The exceptions were postexercise diastolic pressure after four weeks of treatment and lying diastolic pressure after four weeks of treatment. This should be borne
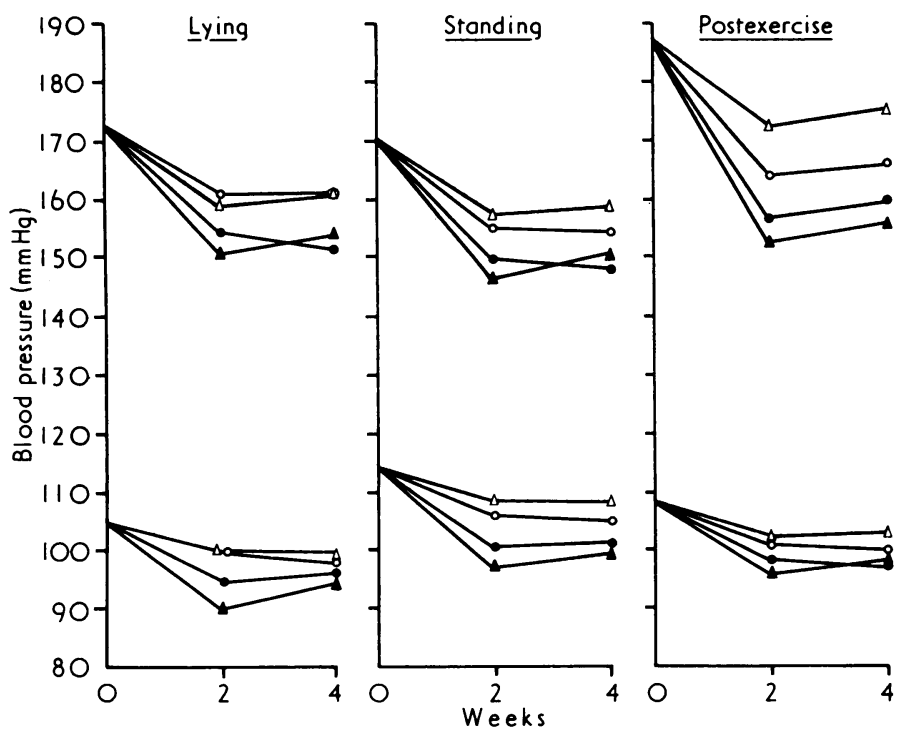

FIG $1-$ Mean blood pressures during treatment. $\Delta \ldots$ Placebo. $0=$ Propranolol $60 \mathrm{mg} /$ day. - Propranolol $120 \mathrm{mg}$ day. $\boldsymbol{\Delta}=$ Propranolol $240 \mathrm{mg}$ day.
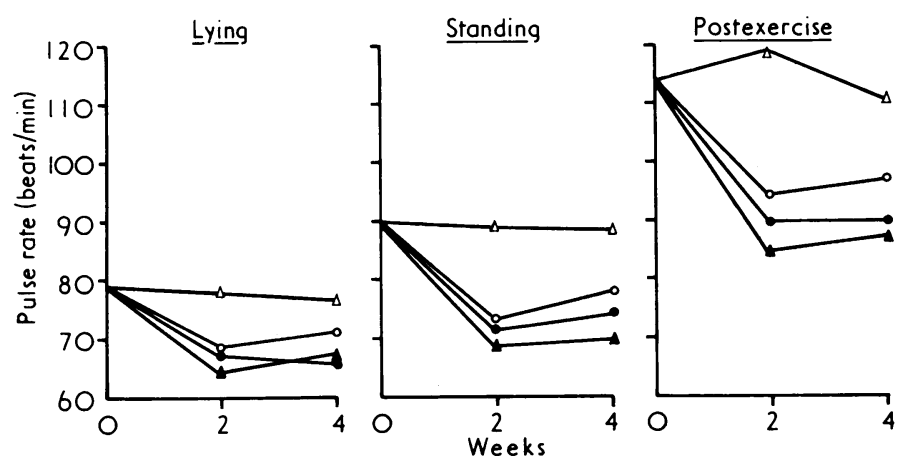

FIG 2-Mean for pulse rates during treatment. See legend to figure 1 for key to treatments. in mind when examining individual treatment comparisons of these variables. The effects of $120 \mathrm{mg} /$ day and $240 \mathrm{mg} /$ day differed little, if at all. The effects of $60 \mathrm{mg} /$ day were not significantly different from those of placebo.

The pulse rate results for the propranolol periods were all significantly different from those for the placebo period. There were no significant differences between the effects of the different doses of propranolol on weight.

Analysis of the questionnaire on side effects showed similar patterns with each dose and with placebo. No dose-related adverse reactions were detected.

\section{SINGLE-DOSE INPATIENT STUDY}

Analysis of the mean levels of lying and standing systolic and diastolic blood pressure showed a significant reduction in mean lying diastolic blood pressure levels at $30,60,90,120$, and 240 minutes with the single $80-\mathrm{mg}$ (13 patients) dose of propranolol over the four-hour period of observation (table III).

TABLE III-Mean blood pressure readings ( $\mathrm{mm} \mathrm{Hg}$ ) 30,60, 90, 120, and 240 minutes after single oral dose of $80 \mathrm{mg}$ propranolol (13 patients)

\begin{tabular}{l|c|c|c|c|c|c}
\hline \multicolumn{1}{c|}{ Time $(\min ):$} & 0 & 30 & 60 & 90 & 120 & 240 \\
\hline Lying systolic & 183 & 174 & 174 & 176 & $168^{*}$ & 175 \\
Lying diastolic & 120 & $111^{*}$ & $111^{*}$ & $110^{*}$ & $107^{*}$ & $107^{*}$ \\
Standing systolic & 182 & 175 & 175 & $171^{*}$ & 174 & $171^{*}$ \\
Standing diastolic & 125 & 120 & $118^{*}$ & $115^{*}$ & 120 & $114^{*}$ \\
\hline
\end{tabular}

${ }^{*} \mathrm{P}<0.05$. Standard error values are available on request to authors.

\section{Discussion}

The results show that in a within-patient comparison of doses oral propranolol $120 \mathrm{mg} /$ day was as effective in lowering blood pressure levels as $240 \mathrm{mg} /$ day. A reduction of about $20 / 10$ $\mathrm{mm} \mathrm{Hg}$ was achieved from a mean initial lying blood pressure of $173 / 104 \mathrm{~mm} \mathrm{Hg}$. Propranolol $60 \mathrm{mg} /$ day was no better than placebo. A minor reduction in lying diastolic pressure was seen within four hours of a single oral dose of $80 \mathrm{mg}$ of propranolol.

The reasons for using a double-blind crossover within-patient design have been outlined elsewhere. ${ }^{2}$ There is also individual variation in the handling of oral propranolol, ${ }^{3}$ and a withinpatient design is therefore particularly appropriate. The doses of propranolol chosen were arbitrary and in the lower ranges because there was a surprising lack of careful work on the response of patients to different doses of propranolol, and some workers may have proceeded to higher doses without waiting long enough to observe the effect of lower doses. We were reluctant to carry out the study using higher doses because the design determined that six previously untreated patients would receive a starting dose of propranolol of $240 \mathrm{mg}$ /day and would be switched after one month directly to placebo. Indeed this was one reason for observing the effects of the $80-\mathrm{mg}$ single oral 
test dose while the patients were in the ward under supervision. Propranolol is reputed not to have an immediate lowering effect on blood pressure and we were surprised to find a reduction over the four-hour period with the higher dose. This suggests that the use of low starting doses of propranolol leads to a slower onset of hypotensive action.

Doubling the dose of propranolol in the outpatient study above $120 \mathrm{mg} /$ day did not cause a statistically significant increase in the hypotensive effect. We have observed this lack of an increase in effect in a group of patients given the cardioselective beta-blocker atenolol, and the lack of an increase in effect has also been shown by others with oxprenolol. ${ }^{4}$ Within-patient comparisons of the doses used in this study with higher dosesfor example, $360 \mathrm{mg}-4 \mathrm{~g} /$ day-would clearly be of interest.

\section{References}

1 Galloway, D B, Beattie, A G, and Petrie, J C, British Heart fournal, 1974 36, 867 .

2 Petrie, J C, et al, British Medical fournal, 1975, 4, 133.
3 Nies, A S, and Shand, D G, New England fournal of Medicine, 1975, 52, 6.

${ }^{4}$ Barritt, D W, Marshall, A J, and Heaton, S, Lancet, 1976, 1, 503.

\title{
Hypophosphataemic osteomalacia in patients receiving haemodialysis
}

\author{
J F MAHONY, J M HAYES, J P INGHAM, S POSEN
}

British Medical fournal, 1976, 2, 142-144

\begin{abstract}
Summary
Four patients had symptomless osteomalacia at the time of starting regular haemodialysis. After 21-40 months they became hypophosphataemic and developed disabling skeletal symptoms. In each case an exacerbation of histological osteomalacia was shown. Symptoms improved after measures designed to raise serum inorganic phosphate concentrations or vitamin $D$ administration, or both. Patients undergoing maintenance haemodialysis should have their serum phosphate and alkaline phosphatase levels monitored every month. Predialysis phosphate levels below $1 \mathrm{mmol} / 1(3 \mathrm{mg} / 100 \mathrm{ml})$ and rising serum alkaline phosphatase concentrations are danger signals. If the diagnosis is confirmed early aggressive treatment should be started.
\end{abstract}

\section{Introduction}

Phosphate-binding agents (such as aluminium hydroxide) are widely used to reduce serum inorganic phosphate in patients with renal failure. ${ }^{12}$ These agents are known to cause phosphate depletion in patients with normal renal function ${ }^{3}$ and in patients with renal failure. ${ }^{+5}$ Hypophosphataemic osteomalacia has been reported. ${ }^{6}$ We have recently seen four patients who became hypophosphataemic and developed severe osteomalacia while receiving maintenance haemodialysis. Our experiences are reported in this paper.

\section{Case 1}

A 16-year-old man with familial renal-retinal dystrophy ${ }^{7}$ presented in renal failure in July 1972. The serum calcium concentration was $1.25 \mathrm{mmol} / 1(5.0 \mathrm{mg} / 100 \mathrm{ml})$, serum inorganic phosphate $2.3 \mathrm{mmol} / 1$

Sydney Hospital, Sydney 2000, Australia

J F MAHONY, MB, FRACP, renal physician

J P INGHAM, MB, FRACP, research fellow

$S$ POSEN, MD, FRACP, associate professor of medicine

St Vincent's Hospital, Darlinghurst 2010, Australia

J M HAYES, MB, FRACP, renal physician
$(7.0 \mathrm{mg} / 100 \mathrm{ml})$, and serum alkaline phosphatase $166 \mathrm{IU} / 1$. Bone $\circ$ $x$-ray films showed a bone age of 11 years but were otherwise normal. Bone biopsy showed osteomalacia with an osteoid index ${ }^{8}$ of 5.0. Treatment with regular haemodialysis was started in July 1972, and $\subseteq$ oral aluminium hydroxide $(2.4 \mathrm{~g}$ daily) was started four months later. The patient received phenytoin in doses ranging from $200-300 \mathrm{mg} /$ day $\vec{\varphi}$ from July 1972 to May 1974 . Serum calcium levels returned to normal within three months of the start of dialysis, while predialysis serum inorganic phosphate levels between October 1973 and May 1974 ranged from 0.55 to $1.2 \mathrm{mmol} / 1(1.7-3.6 \mathrm{mg} / 100 \mathrm{ml}$ ) (mean 0.71 mmol $/ 1$ $(2 \cdot 2 \mathrm{mg} / 100 \mathrm{ml}))$. Serum alkaline phosphatase gradually rose to $\bar{\partial}$ $1150 \mathrm{IU} / \mathrm{l}$. Serum immunoreactive parathyroid hormone levels ranged from $0 \cdot 6-2 \cdot 4 \mu \mathrm{g} / \mathrm{l}$. On 9 May 1974 he was admitted with severe pain $\mathbb{D}$ in the limbs and inability to walk. Pelvic $x$-ray examination showed $\cong$ Looser zones, and a repeat bone biopsy showed severe osteomalacia $\overrightarrow{\overrightarrow{0}}$ with an osteoid index of 30 .

The patient was treated with $2.5 \mathrm{mg}$ dihydrotachysterol per day, and aluminium hydroxide treatment was discontinued. These measures $O$ were followed by complete symptomatic relief in six weeks. Predialysis serum inorganic phosphate levels rose to $1.3 \mathrm{mmol} / 1(4.0 \mathrm{mg} / 100 \mathrm{ml})$ or greater. Serum alkaline phosphatase activities initially rose to $2500 \mathrm{IU} / 1$ and fell to $200 \mathrm{IU} / 1$ three months later. The patient $\frac{3}{3}$ resumed aluminium hydroxide treatment and continued to take dihydrotachysterol ( $0.625 \mathrm{mg} /$ day $)$.

\section{Case 2}

A 21-year-old man with membranoproliferative glomerulonephritis started regular haemodialysis in March 1970, when he was 17. At that time he also started taking aluminium hydroxide $(1.8 \mathrm{~g}$ daily) without apparent ill-effect. He received a cadaveric renal allograft $ᄋ$ in June 1971, but it was removed seven months later because of $\omega$ chronic rejection. Regular haemodialysis and aluminium hydroxide treatment were resumed at that time. Because of intractable hyper- 0 tension he underwent bilateral nephrectomy in February 1972, and $\overparen{\Phi}$ was trained for domiciliary haemodialysis two months later. Skeletal $\stackrel{\oplus}{\rightarrow}$ $x$-ray examination in May 1973 showed a bone age of 16 years and 7 subperiosteal resorption of the phalanges. Skeletal histology showed $\vec{O}^{\circ}$ mild hyperparathyroidism and severe osteomalacia with an osteoid $\overrightarrow{\mathbb{D}}$ index of $16 \cdot 2$. The mean predialysis serum inorganic phosphate $\frac{?}{\mathbb{Q}}$ concentration between November 1973 and May 1974 was $0.9 \mathrm{mmol} / 1$ 음 $(2.8 \mathrm{mg} / 100 \mathrm{ml})$, and the mean predialysis calcium level was 2.45 ? $\mathrm{mmol} / 1(9.8 \mathrm{mg} / 100 \mathrm{ml})$. Serum alkaline phosphatase gradually rose $ᄋ$ to $923 \mathrm{IU} / 1$. The mean predialysis serum immunoreactive parathyroid응 hormone level was $4 \cdot 2 \mathrm{\mu g} / \mathrm{l}$.

In May 1974 he was admitted because of generalised muscle weak- $\frac{\overline{0}}{7}$ ness and pain in the limbs which were so severe that he was unable to ? walk. Skeletal $x$-ray films showed rachitic changes, and a repeat bone biopsy showed an osteoid index of about 30. Aluminium hydroxide was withdrawn and dihydrotachysterol $(0.625 \mathrm{mg} /$ day $)$ was prescribed. 